


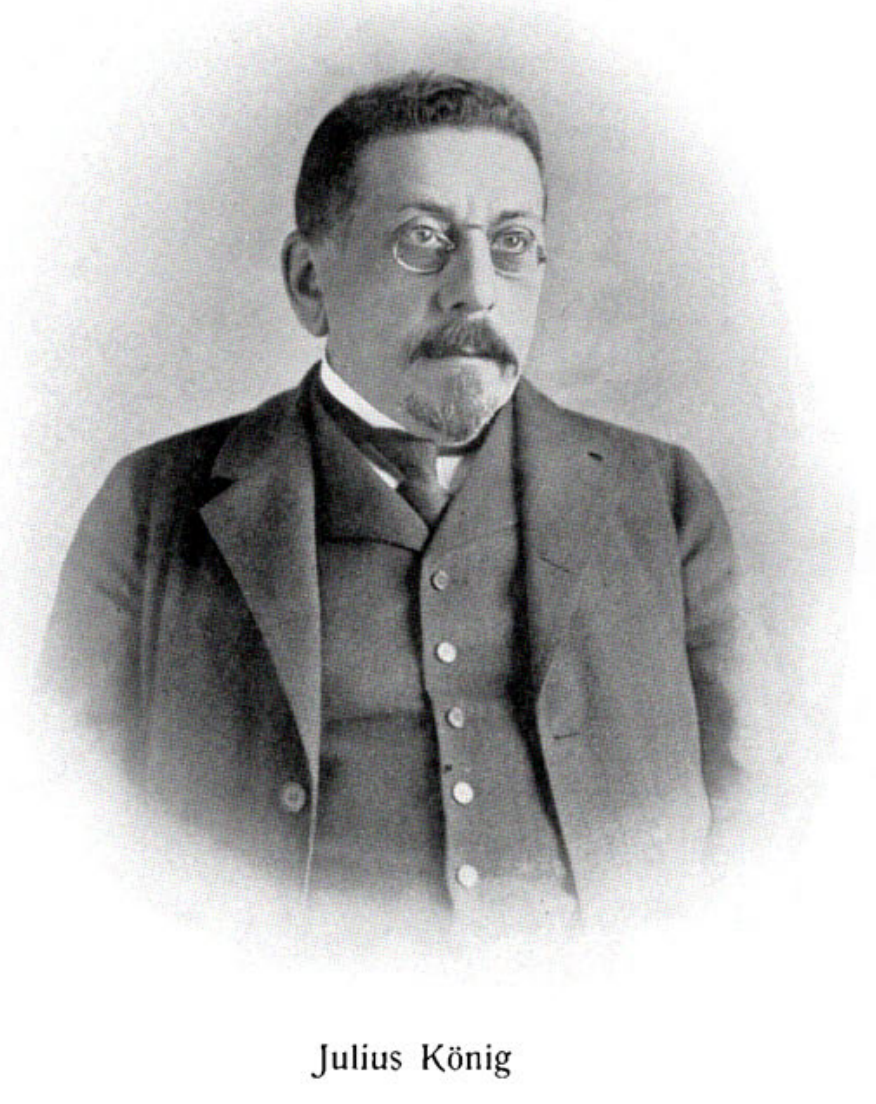




\title{
NEUE GRUNDLAGEN DER LOGIK, ARITHMETIK UND MENGENLEHRE
}

\author{
VON \\ JULIUS KÖNIG \\ SEKRETÄR DER MATH. UND NATURWISS. KLASSE \\ DER UNGARISCHEN AKADEMIE DER WISSENSCHAFTEN
}

MIT DEM BILDNIS DES VERFASSERS

LEIPZIG

VERLAG VON VEIT \& COMP. 
Druck von Metzger \& Wittig in Leipzig. 